\title{
EFEKTIFITAS PEMBERIAN DISPENSASI KAWIN PADA ANAK DI BAWAH UMUR MENURUT UNDANG-UNDANG NO.1 TAHUN 1974 (STUDI KASUS DI KAB. POLEWALI MANDAR)
}

\begin{abstract}
Ade Rahayu*
ABSTRACT

Marriage dispensation is the relief of something (age limit) in bonding between a man and a woman as husband and wife with the aim of forming a happy and eternal family based on the One Godhead. The purpose of this study was to determine and analyze the effectiveness of Marriage Dispensation in Underage Children in Polewali Mandar Regency and the factors that influence the judge's decision to grant the request for mating dispensation in minors in Polewali Mandar district. The research method used is empirical legal research. The results showed that underage marriage in Polewali Mandar district had not been implemented effectively because underage marriage was still found without going through mating dispensation and the factors that influenced the judge's decision to grant the request were because the prospective bride had been pregnant out of wedlock. Because the judge is not bound by positive law so the judge is given the opportunity to find the law. The judge prioritizes the concept of maslahah mursalah, where the judge chooses consideration of goodness and rejects damage in society and prevents harm.
\end{abstract}

Keywords: effectiveness, dispensation of marrying minors, age of marriage

\section{PENDAHULUAN}

Pernikahan merupakan sunnatullah yang umum dan berlaku pada semua makhluknya baik pada manusia, hewan maupun tumbuh-tumbuhan. Pernikahan adalah salah satu cara yang dipilih oleh Allah SWT. Sebagai jalan bagi makhluknya untuk berkembang biak dan melestarikan hidupnya. Pernikahan akan berperan setelah masing-masing pasangannya sudah melakukan perannya masing-masing yang positif dalam mewujudkan pernikahan tersebut. Akan tetapi manusia mempunyai aturan-aturan untuk

*) Prodi PPKn, Universitas Al Asyariah Mandar, E-mail: Adherahayu86@gmail.com 
melaksanakannya yang tidak boleh bertindak semaunya seperti makhluk lainnya. Hal ini juga merupakan sunnah Rasulullah S.A.W yang tinggi derajatnya dan luhur nilainya. Sehingga islam sangat menganjurkan perkawinan atau pernikahan ini dilakukan bagi yang telah mempunyai kemampuan agar seorang muslim dapat menjauhkan dirinya dari segala dorongan syahwat yang dapat mendekatkannya dengan perbuatan zina.

Secara manusiawi pastilah setiap manusia menginginkan perkawinan. Sebab sejak dilahirkan manusia telah dilengkapi dengan naluri untuk senantiasa hidup bersama dengan orang lain yang menimbulkan hasrat yang kuat untuk hidup secara teratur dalam masyarakat yang akhirnya membentuk bangsa dan negara.

Manusia juga diciptakan untuk saling mengenal, saling membutuhkan, saling berdampingan dan saling berkasih sayang. Yang paling utama manusia itu diciptakan oleh Allah SWT berpasang-pasangan seperti halnya Adam dan Hawa.

Untuk mencapai tujuan pernikahan tersebut sangat dibutuhkan kedewasaan seseorang, baik secara fisik maupun mental agar pasangan dapat mengerti tanggung jawabnya masing-masing dan dapat mempersiapkan diri dalam hidup berkeluarga. Perkawinan merupakan satu hal yang dilakukan dengan serius yang mengakibatkan sesorang akan terikat seumur hidup dengan pasangannya. Oleh karena itu, perkawinan membutuhkan kesiapan yang matang yaitu kematangan fisik dan kedewasaan mental. Kematangan fisik merupakan potensi yang sangat dominan terhadap keharmonisan rumah tangga. Hal tersebut dapat mewujudkan perkawinan yang baik tanpa diakhiri dengan perceraian dan mendapatkan keturunan yang sehat.

Oleh karena itu, dalam Undang-Undang No. 1 Tahun 1974 tentang perkawinan diatur mengenai batas umur meinimal seseorang untuk melangsungkan perkawinan yang dijelaskan dalam pasal 7 ayat 1 yaitu:

"Perkawinan hanya diizinkan jika pihak pria sudah mencapai umur 19 (sembilan belas) tahun dan pihak wanita sudah mencapai 16 (enam belas) tahun".

Apabila terjadi penyimpangan terhadap batas umur diizinkannya melangsungkan perkawinan hanya dimungkinkan dengan meminta dispensasi kepada pengadilan atau pejabat lain yang ditunjuk oleh kedua orang tua pihak pria maupun wanita sepanjang hukum masing-masing agama yang bersangkutan tidak menentukan lain. Hal ini diatur dalam Pasal 7 ayat (2) Undang-Undang No. 1 Tahun 1974.

Kompilasi Hukum Islam (KHI) juga memuat aturan yang kurang lebih sama. Pada pasal 15, Kompilasi Hukum Islam menyebutkan bahwa batas usia 
perkawinan sama seperti pasal 7 Undang-Undang No. 1 Tahun 1974. Demikian juga masalah dispensasi perkawinan dibawah umur. Bedanya, didalam KHI disebutkan sebuah alasan mengapa dispensasi itu dapat diberikan, yaitu untuk kemaslahatan keluarga dan rumah tangga.

Adapun dalam islam memang tidak pernah secara spesifik membahas tentang usia perkawinan, Al-Quran hanya menetapkan dengan tanda-tanda dan isyarat terserah kepada kaum muslimin untuk menentukan batas umur yang sebaiknya yang sesuai dengan syarat dan tanda-tanda yang telah ditentukan, dan disesuaikan dengan tempat dimana hukum itu akan diundangkan. Akan tetapi dalam kenyataannya dalam masyarakat banyak yang melakukan penyimpangan dengan mengabaikan hal tersebut sebab menurut penulis Undang-Undang hanya sekedar formalitas yang apabila calon mempelai belum mencukupi batas umur yang telah ditentukan maka harus mengajukan permohonan dispensasi kawin di pengadilan Agama dan pengadilan-pun mengabulkannya. Peranan Kantor Urusan Agama (KUA) disini sangat penting sebab pendaftaran nikah dilakukan di KUA. Kepala KUA sebagai Pejabat Pencatat Nikah (PPN), yang kadang melakukan penyimpangan hal tersebut dengan cara menikahkan anak di bawah umur tanpa melalui dispensasi kawin di pengadilan agama setempat. Sehingga dari penyimpangan tersebut PPN yang melakukan bisa saja diberikan sanksi atas perbuatannya.

Dengan memperhatikan kehidupan masyarakat di wilayah kabupaten Polewali Mandar, banyak diantaranya telah menikah di bawah umur yang entah pernikahan tersebut melalui jalur dispensasi kawin atau tidak. Oleh sebab itu penulis berinisiatif untuk mengkaji lebih dalam dan meneliti tentang aturanaturan dispensasi kawin dengan mengangkat judul "Efektifitas Pemberian Dispensasi Kawin Pada Anak di Bawah Umur Menurut Undang-undang No.1 Tahun 1974 Tentang Perkawinan (studi di Kabupaten Polewali Mandar)"

\section{Kerangka Konsep}

Hukum perkawinan merupakan bagian dari Hukum Islam yang memuat ketentuan-ketentuan tentang hal ikhwal perkawinan yaitu bagaimana prosedur menuju terbentuknya ikatan perkawinan, bagaimana cara menyelenggarakan aqad perkawinan menurut hukum, bagaimana cara mengatasi krisis rumah tangga yang mengancam ikatan lahir batin antara suami dan isteri, bagaimana proses dan prosedur dari berakhirnya perkawinan serta akibat yuridis dari berakhirnya perkawinan baik yang menyangkut hubungan hukum antara bekas suami dan isteri, anak-anak mereka dan harta mereka. Untuk tercapainya hal 
tersebut jika memasuki jenjang pernikahan maka dibutuhkan persiapanpersiapan matang; kematangan fisik, psikis, maupun spiritual.

Dalam hukum perkawinan diatur tentang batas umur seseorang boleh tidaknya untuk menikah yang tertuang dalam pasal 7 ayat (1) Undang-undang No.1 Tahun 1974 . yang jika ada belum cukup umur tetapi ingin menikah maka harus meminta dispensasi terlebih dahulu di Pengadilan Agama. Dispensasi perkawinan adalah keringanan akan sesuatu (batasan umur) di dalam melakukan ikatan antara seorang pria dengan seorang wanita sebagai suami isteri dengan tujuan membentuk keluarga (rumah tangga) yang bahagia dan kekal berdasarkan Ketuhanan Yang Maha Esa.

Sebagaimana dibahas diatas, bahwa jika hendak menikahkan anak di bawah umur, maka harus diajukan permohonan ke pengadilan. Disinilah peran hakim sebagai penentu. Jika hakim mengijinkan, maka akan terjadi pernikahan tersebut. Sebaliknya, jika hakim menolak maka perkawinan tersebut tidak dapat dilaksanakan.

Adanya putusan Hakim tersebut sangat diharapkan dapat menciptakan tujuan hukum yang sebenarnya yaitu keadilan, namun kiranya dalam setiap penerapan hukum senantiasa mensinergikan antar ketiga tujuan hukum yaitu kemanfaatan, keadilan dan kepastian hukum, agar ketiga nilai dasar hukum tersebut dapat terwujud secara bersama-sama tanpa ada pengabaian dan kepincangan antar satu dengan yang lain.

\section{METODE PENELITIAN}

Penelitian ini menggunakan tipe penelitian hukum empiris yaitu dengan memusatkan perhatian pada prinsip-prinsip umum yang mendasari suatu gejalagejala yang terjadi dalam kehidupan manusia dengan mengkaji data-data dan membaca literatur-literatur yang berkaitan dengan judul penelitian.

\section{HASIL DAN PEMBAHASAN}

Polewali Mandar merupakan salah satu daerah yang banyak melakukan pernikahan di bawah umur terutama di Kecamatan Wonomulyo. Hal ini disebabkan masyarakatnya lebih dominan berpenghasilan sebagai pedagang sehingga banyak para orang tua lebih memilih menikahkan anaknya dari pada menyekolahkannya tinggi-tinggi. Para orang tua tersebut berfikiran agar anaknya meneruskan usahanya. Selain itu para orang tua takut akan pergaulan bebas anak sekarang sehingga mereka lebih memilih menikahkan anaknya cepat. 
Hal ini cenderung banyak terjadi di Kecamatan Wonomulyo, sesuai data-data yang diperoleh penulis di Pengadilan Agama Polewali.

Kantor Urusan Agama di wilayah Kecamatan Wonomulyo merupakan tempat pencatatan perkawinan untuk masyarakat wilayah Wonomulyo. Berdiri sejak tahun 1965 dibangun di atas tanah wakaf yang terletak di wilayah Timur dari ibu kota kecamatan bertempat di Jalan Jenderal Sudirman No.38 Kelurahan Sidodadi, yang memiliki visi yaitu "Terwujudnya Masyarakat Wonomulyo yang Taat Beragama, Rukun, Cerdas, Mandiri, dan Sejahtera Lahir Batin " dan misinya yaitu :

a. Meningkatkan Kualitas Pelayanan Nikah dan Rujuk.

b. Meningkatkan Kualitas Pelayanan Wakaf.

c. Meningkatkan kualitas Pembinaan dan Bimbingan Keluarga Sakinah.

d. Meningkatkan Kualitas Pembinaan dan Bimbingan Ibadah Haji.

e. Meningkatkan Kualitas Kerukunan antarumat beragama.

f. Meningkatkan kualitas Tata Kelola Organisasi dalam mewujudkan pemerintah yang bersih dan berwibawa.

Dari salah satu misi tersebut dalam poin a dan c, ini dapat dikaitkan dengan permohonan dispensasi Kawin yang dilakukan di Pengadilan Agama. Sebelum mengajukan permohonan, pemohon dispensasi telah mendapatkan penolakan dari Kantor Urusan Agama daerah setempat karena tidak memenuhi syarat perkawinan.

Pemohon yang dimaksud adalah orang tua dari anak yang belum cukup umur untuk dinikahkan yang menyalahi Undang-undang No. 1 Tahun 1974. Karena untuk mendapatkan keabsahan perkawinan di mata hukum dan negara harus melalui pencatatan perkawinan yang dalam hal ini merupakan wewenang dari Kantor Urusan Agama sesuai Undang-undang No 22 Tahun 1946 Tentang pencatatan nikah,talak, dan rujuk. Sebagaimana dalam negara yang teratur segala hal-hal yang bersangkut paut dengan penduduk harus di catat, sebagai kelahiran, pernikahan, kematian dan sebagainya perkawinan perlu dicatat menjaga jangan sampai ada kekacauan.

Berdasarkan hasil penelitian yang diperoleh di Pengadilan Agama Polewali selama Tahun 2015 terdapat 63 (Enam Puluh Tiga) perkara permohonan Dispensasi Kawin Anak Di Bawah Umur. Perkara tersebut dominan berasal dari KUA Wonomulyo. Pihak KUA sendiri telah melakukan penyuluhan-penyuluhan di kelurahan-kelurahan terhadap Undang-undang Nomor 1 Tahun 1974 Tentang Perkawinan. Maka dari itu masyarakat sudah mengetahui hal tersebut. 
Tetapi dalam kenyataannya ada sebagian pasangan yang melakukan perkawinan di bawah umur mengetahui keberadaan dari Undang-Undang Nomor 1 Tahun 1974 Tentang Perkawinan, namun kehendak dari pasangan tersebutlah yang membuat mereka harus secepatnya menikah tanpa menghiraukan aturan hukum perkawinan yang berlaku di negara kita, yang mengatur tentang adanya syarat seseorang yang harus dipenuhi yaitu syarat usia kedua calon mempelai.

Dari penyuluhan yang dilakukan KUA, maka seharusnya masyarakat sudah mengetahui tentang syarat-syarat apa saja yang harus dipenuhi jika ingin melangsungkan perkawinan yang sah di mata Hukum dan Agama. Akan tetapi, ada sebagian kecil masyarakat yang tidak mengetahui hal-hal tersebut, kemungkinan dikarenakan masyarakat tidak menghadiri penyuluhan yang telah diselenggarakan pihak KUA. Dengan adanya penyuluhan maka masyarakat memahami bahwa Perkawinan akan dilaksanakan jika memenuhi Syarat-syarat yang terdapat pada Undang-Undang Nomor 1 Tahun 1974 Tentang Perkawinan yang jika umur belum memenuhi syarat maka harus meminta dispensasi terlebih dahulu di Pengadilan Agama setempat, jika tidak memenuhi syarat tersebut pihak KUA akan melakukan penolakan terhadap pernikahan itu.

Faktor yang menyebabkan pernikahan di bawah umur adalah faktor lingkungan dan faktor ekonomi. Faktor lingkungan yang dimakasud adalah pergaulan anak-anak sekarang semakin bebas dengan perkembangan teknologi yang tidak terkontrol, gencarnya ekspose seks media massa menyebabkan remaja modern kian permisif terhadap seks. Para orang tua khawatir kena aib karena anak-anaknya yang berpacaran sangat lengket sehingga segera menikahkan anaknya. Faktor ekonomi yang dimaksud yaitu karena keadaan orang tua yang hidup di garis kemiskinan mereka menikahkan anak perempuannya kepada laki-laki yang dianggap mampu, selain itu faktor ekonomi masyarakat Wonomulyo yang kebanyakan berpenghasilan pedagang yang lebih memilih menikahkan anaknya daripada menyekolahkannya tinggitinggi.

Kepala KUA Wonomulyo menyatakan bahwa alasan orang tua menikahkan anaknya yang masih di bawah umur karena orang tua ingin segera mendapatkan tambahan anggota keluarga dan sifat kolot mereka yang tidak mau menyimpang dari ketentuan adat yang masih mengikuti adat kebiasaan mereka bahwa umur tidak masalah dalam perkawinan karena orang-orang jaman dahulu juga lebih muda lagi dari standar umur sesuai ketentuan Undangundang No.1 Tahun 1974, orang tua berfikiran jika anaknya sudah mimpi basah atau telah haid maka sudah dapat dinikahkan. 
Perkawinan di bawah umur tanpa dispensasi kawin ini, dikarenakan para pihak memandang ada cara pintas yang dapat ditempuh untuk melangsungkan perkawinan di bawah umur tanpa dispensasi kawin yaitu dengan melakukan pemalsuan umur, sehingga para pihak beranggapan bahwa dispensasi kawin yang pada dasarnya sangat penting menjadi tidak penting. Akan tetapi hal ini tidak ditemukan di KUA Wonomulyo.

Sebagaimana yang dikatakan oleh bapak Ibrahim selaku kepala Kantor Urusan Agama Wonomulyo bahwa setiap orang yang ingin melangsungkan perkawinan harus memberitahukan kehendaknya itu kepada Pegawai Pencatat Nikah dalam hal ini KUA. Hal tersebut telah dilakukan dengan memeriksa apakah orang tersebut sudah melengkapi syarat-syarat yang ditentukan ( PP No. 9 Tahun 1975), pemberitahuan ini dilakukan selambat-lambatnya 10 hari sebelum perkawinan dilangsungkan. Pemberitahuan tersebut memuat nama, umur, agama/kepercayaan, pekerjaan, tempat kediaman calon mempelai dan apabila salah seorang atau keduanya pernah kawin, disebutkan juga nama isteri atau suami terdahulu. Maka dari itu jika umur calon mempelai belum cukup umur maka dibuatkan penolakan perkawinan dan hal itu harus meminta dispensasi kawin di Pengadilan Agama setempat agar dapat melangsungkan perkawinan.

Jika calon mempelai pernah menikah sebelumnya dan telah mendapatkan dispensasi dari perkawinan sebelumnya sedangkan dia masih di bawah umur, maka tidak perlu lagi meminta dispensasi untuk kedua kalinya.

Salah satu faktor penghambat pemberian dispensasi kawin di Pengadilan Agama Polewali yaitu jika kedua anak telah saling mencintai tetapi orang tua salah satu pihak atau keduanya tidak merestui perkawinan anaknya, maka yang memohon dispensasi tersebut boleh anak itu sendiri dengan cara permohonan wali adol terlebih dahulu. Meskipun dalam aturan yang harus bermohon dispensasi di pengadilan itu harus orang tua anak yang belum cukup umur untuk menikah dengan syarat bahwa perempuannya sudah terlanjur hamil. Maka jika orang tuanya tidak menyetujui si anak dapat meminta wali adhol ke Pengadilan Agama setempat. Sebagaimana pengertian "wali adhol" adalah wali yang ditunjuk oleh hakim untuk menikahkan seseorang yang tidak direstui oleh orang tuanya. Wali adol harus sesuai dengan yang dibenarkan oleh syara' yaitu islam, dewasa, dan laki-laki. Hal tersebut terjadi karena belum matangnya pemikiran sehingga sering juga terjadi perundingan bijaksana yang tidak bermanfaat dan ketika perkawinan tidak mungkin lagi dipertahankan maka mereka memilih jalan untuk berpisah. 
Oleh karena itu akibat hukum yang dapat ditimbulkan dari pelaksanaan perkawinan di bawah umur tanpa dispensasi kawin yaitu: Pencatatan perkawinan itu tidak memenuhi persyaratan yang telah ditentukan dalam pasal 7 Undang-undang Nomor 1 tahun 1974 tentang perkawinan jo Pasal 6 ayat (2) huruf (e) Peraturan Pemerintah No.9 Tahun 1975. Jadi apabila dilihat dari aspek administrasi atau pencatatan perkawinan. Perkawinan tersebut batal demi hukum, karena tidak memenuhi persyaratan yang telah ditentukan dalam perundang-undangan yang berlaku dan Menurut ketentuan KHI dalam pasal 15 perkawinan tanpa dispensasi merupakan pelanggaran terhadap undang-undang perkawinan. Sedangkan menurut ketentuan dalam fiqih, status perkawinan tersebut adalah sah karena telah memenuhi rukun dan syarat hukum islam dalam perkawinan.

Setelah ditelaah ternyata pihak KUA melakukan penyimpangan karena alasan waktu dan biaya. Maka dari itu dapat ditarik kesimpulan bahwa pelaksanaan pemberian dispensasi kawin di Kabupaten Polewali Mandar belum dilaksanakan secara efektif.

Apabila alasan KUA atau PPN melakukan penyimpangan UU No.1 Tahun 1974 dengan tidak melalui dispensasi kawin karena kekurangan biaya seharusnya PPN memberi tahu kepada masyarakat yang tidak mampu bahwa ada upaya Prodeo (bebas biaya) dari pengadilan agama. Jadi, tidak ada alasan apapun untuk tidak melalui jalur dispensasi kawin.

Menurut bapak Ibrahim pihak KUA bisa saja mengawinkan anak di bawah umur tidak melalui jalur dispensasi sepanjang tidak ada keberatan dengan pernikahan tersebut, sehingga resiko yang dapat ditimbulkan adalah pernikahan tersebut dapat dibatalkan. Selain itu pihak KUA sendiri dapat dikenakan sanksi jika hal tersebut diketahui, karena menikahkan anak di bawah umur tidak melalui dispensasi kawin di Pengadilan Agama.

Dirjen Bimas Islam depag, Prof. Dr. Nasaruddin Umar mengatakan dalam artikelnya bahwa sedang dirancang Undang-undang Terapan Peradilan Agama tentang perkawinan yang akan menghadang perkawinan di bawah umur dengan sanksi yang jelas, sanksi yang deikenakan yaitu bagi pelaku perkawinan di bawah umur mencapai Rp.6.000.000,- (enam juta rupiah) dan sanksi untuk penghulu yang mengawinkannya sebesar Rp. 12.000.000,- (dua belas juta rupiah) dan kurungan tiga bulan.

Menyinggung dengan pernikahan yang dilakukan oleh sejumlah pemuka agama dengan pernikahan siri, bukan pernikahan yang dicatatkan pada KUA, maka harus dilakukan sosialisasi secara rutin diharapkan bahwa para pemuka 
agama tidak menikahkan pasangan calon suami isteri, karena merugikan terutama perempuan, mengingat karena tidak tercatat secara resmi.

Faktor-faktor Yang Mempengaruhi Keputusan Hakim dalam Mengabulkan Permohonan Dispensasi Kawin Pada Anak di Bawah Umur di Kabupaten Polewali Mandar.

Berdasarkan hasil penelitian di Pengadilan Agama Polewali Mandar terdapat 63 (enam puluh tiga) perkara dispensasi kawin selama Tahun 2015. Dari perkara-perkara tersebut diambil salah satu Penetapan sebagai sampel untuk melihat pertimbangan-pertimbangan hakim dalam mengabulkan permohonan tersebut. Salah satunya adalah Penetapan No. 30/Pdt.P/2015/PA.Pwl

Dalam penetapan tersebut, pemohon meminta dispensasi kawin di Pengadilan Agama Polewali karena Kantor Urusan Agama Wonomulyo telah menolak perkawinan anaknya dengan alasan anak pemohon masih berumur 18 Tahun 5 bulan yang seharusnya berumur 19 Tahun agar dapat dikatakan sah di hadapan hukum.

Dalam suatu proses persidangan, pihak calon suami/atau isteri dari yang dimohonkan dispensasi biasanya dipanggil untuk memberikan keterangan tentang adanya pernikahan yang akan dilangsungkan tetapi dia tidak disebut sebagai saksi hanya dinamakan pemberi keterangan. Sebab saksi merupakan seseorang pemberi keterangan yang tidak berkepentingan sedangkan calon suami/isteri tersebut berkepentingan dalam dikabulkan atau tidaknya permohonan tersebut. Hal ini bukan peraturan yang mutlak dalam suatu persidangan dispensasi. Calon suami/ istri tersebut dihadirkan oleh pihak pemohon saja bukan dari Permintaan Pengadilan.

Sebagaimana juga dengan apa yang dikatakan oleh H. A. Zahri selaku hakim Ketua dalam menangani perkara dispensasi kawin bahwa sebagai pertimbangan hakim untuk mengabulkan permohonan dispensasi kawin yaitu dengan melihat layak tidaknya anak pemohon diberi dispensasi, kelayakan ini dilihat dari Kedewasaan secara rohaniah, Kesiapan calon mempelai dan Tanpa adanya paksaan dari orang tua.

Menurut Zulkifli sebagai Hakim Pengadilan Agama Polewali menyebut perlunya dipertimbangkan 4 (empat) sudut peninjauan sebelum perkawinan berlangsung yaitu : Pertimbangan dari sudut biologis/seksual, ekonomi, pendidikan, dan masyarakat.

Dalam ajaran agama islam sendiri tentang umur berapa boleh menikah tidak dijelaskan batas umur kawin. Secara tegas hanya melihat kepada besarnya tanggung jawab masing-masing suami isteri maka diharapkan perkawinan 
tersebut dilakukan setelah mampu fisik, harta dan memiliki kematangan pemikiran dan tanggung jawab.

Sebagaimana yang terdapat dalam pasal 15 ayat 1 Kompilasi Hukum Islam yang menerangkan bahwa :

"Untuk kemaslahatan keluarga dan rumah tangga perkawinan hanya boleh dilakukan calon mempelai yang telah mencapai umur yang ditetapkan dalam pasal 7 Undang-undang No.1 tahun 1974 yakni calon suami sekurang-kurangnya berumur 19 Tahun dan calon isteri sekurang-kurangnya 16 tahun".

Akan tetapi bukannya melahirkan kemaslahatan keluarga dan rumah tangga, pernikahan di bawah umur justru banyak berujung pada perceraian. Di samping itu, ada dampak lain yang lebih luas, seperti meningkatnya angka kematian ibu saat hamil atau melahirkan lantaran masih berusia belia.

Sebagaimana diketahui bahwa karena tidak adanya aturan-aturan mengenai alasan diberikan dispensasi kawin melainkan dengan penilaian hakim. Dengan melihat pertimbangan-pertimbangan hakim dalam putusan tersebut dan hasil dari wawancara beberapa hakim. Maka, dari perkara-perkara dispensasi kawin, hakim-hakim Pengadilan Agama Polewali yang menangani perkara dispensasi kawin telah mengeluarkan penetapan yang mengabulkan permohonan pemohon dan mengabulkannya dengan alasan-alasan sebagai berikut, yaitu:

a. Karena kedua calon mempelai telah saling mencintai.

b. Karena calon mempelai wanita telah dewasa menurut islam (haid/menstruasi).

c. Karena calon mempelai wanita telah mempunyai kemampuan baik secara fisik maupun mental untuk membina rumah tangga.

d. Karena calon mempelai wanita telah mampu melaksanakan tugas atau kewajiban suami isteri dan membina rumah tangga.

e. Karena calon mempelai lelaki mampu memberi nafkah lahir dan batin kepada calon isterinya.

f. Karena lelaki telah mempunyai penghasilan yang cukup untuk membina rumah tangga.

g. Karena telah melakukan hubungan biologis sehingga mengakibatkan hamil diluar nikah.

h. Karena dengan pertimbangan sosial yaitu kedua anak tersebut memiliki gejolak pernikahan yang tinggi sehingga jika dipisahkan akan menimbulkan kemudharatan

Sedangkan hal yang biasanya menyebabkan permohonan dispensasi kawin terhadap anak di bawah umur itu tidak dikabulkan yaitu jika dari proses 
persidangan diketahui bahwa ternyata calon suami/isteri masih terikat hubungan perkawinan dengan orang lain.

Tabel 1. Jawaban Dari Pasangan yang Menikah Di Bawah Umur Tentang Kehidupan Rumah Tangga Setelah Menikah

\begin{tabular}{llll}
\hline No & $\begin{array}{l}\text { Jawaban } \\
\text { Responden }\end{array}$ & Jumlah & Persentase \\
\hline 1 & Baik & 17 & $68 \%$ \\
2 & Tidak & 8 & $32 \%$ \\
& Baik & & \\
& & 25 & $100 \%$ \\
\hline
\end{tabular}

Berdasarkan data diatas bahwa ada 8 pasangan dari 25 pasangan yang sudah tidak bersama lagi. Menurut bapak Salahuddin selaku wakil ketua Pengadilan Agama mengatakan bahwa hal yang menjadikan penghambat pemberian dispensasi kawin dengan melihat pasangan yang baru beberapa waktu yang tidak cukup lama datang lagi ke Pengadilan Agama untuk memohon perceraian. Padahal waktu perkara di sidangkan para calon mempelai mengatakan tidak ada paksaan dan saling suka sama suka.

Berdasarkan apa yang diuraikan di atas dapat diketahui bahwa Faktorfaktor yang mempengaruhi keputusan hakim dalam mengabulkan permohonan dispensasi kawin pada anak di bawah umur yaitu salah satunya adalah hamil di luar nikah sehingga jalan yang sering ditempuh oleh orang tua yaitu mengajukan permohonan dispensasi nikah melalui Pengadilan Agama. Alasan tersebut mempengaruhi sikap para hakim di pengadilan atau pejabat lain yang ditunjuk dalam mengambil keputusan untuk memberikan dispensasi kawin bagi para pihak. Sementara itu setiap anak yang belum cukup umur harus mendapatkan perlindungan akan hak-hak anak dan kesejahteraan sebagaimana yang diamanatkan oleh undang-undang perlindungan anak.

Hati nurani dan kebaikan hakim dapat juga menjadi faktor dikabulkannya dispensasi nikah dengan tujuan untuk kemaslahatan karena jika tidak dikabulkan akan dikhawatirkan terjadi pernikahan siri yang mengakibatkan kekacauan nasib anaknya kelak.

Dalam mengambil keputusan hakim menganut aliran interesenjurisprudens ( freirechtslehre). Aliran ini berpendapat bahwa undang-undang jelas tidaklah lengkap. Undang-undang bukan satu-satunya sumber hukum, sedangkan hakim dan pejabat lainnya mempunyai kebebasan yang seluas-luasnya untuk melakukan penemuan hukum, jadi hakim bukan sekedar menerapkan undangundang saja, tetapi juga mencakup, memperluas dan membentuk peraturan 
dalam putusan hakim. Dapat diartikan walaupun dalam undang-undang telah diatur batasan usia untuk melakukan perkawinan yaitu bagi laki-laki minimal berusia 19 tahun dan bagi wanita minimal berusia 16 tahun tetapi hakim dapat mengabulkan permohonan dispensasi usia perkawinan karena suatu keadaan yang sangat mendesak karena kerusakan/mafiadsnya lebih besar jika permohonan dispensasi kawinnya ditolak yaitu dikhawatirkan terjadi hal-hal yang tidak diinginkan dimana orang tua khawatir akan hubungan anak dengan pasangannya yang sudah terlalu jauh.

Untuk mencapai keadilan yang setinggi-tingginya, bahkan hakim boleh menyimpang dari undang-undang, demi kemanfaatan masyarakat. Jadi disini hakim mempunyai freis ermessen. Ukuran-ukuran dengan kesadaran hukum dan keyakinan warga masyarakat, tergantung pada ukuran dari keyakinan hakim, dimana kedudukan hakim bebas mutlak.

\section{SIMPULAN}

Berdasarkan apa yang diuraikan diatas maka dapat disimpulkan bahwa Perkawinan di bawah umur di kabupaten Polewali Mandar sebagian besar dilakukan dengan melalui prosedur yang sebenarnya, berdasarkan ketentuan Undang-undang Nomor 1 Tahun 1974 melalui pembantu pencatat nikah dan tercatat di Kantor Urusan Agama (KUA). Adapun cara pemenuhan prosedur dilakukan yaitu dengan memohon dispensasi kawin di Pengadilan Agama setempat karena adanya penolakan dari Kantor Urusan Agama. Selain itu masih juga ditemukan perkawinan di bawah umur tanpa melalui jalur dispensasi kawin dan hal itu mengakibatkan batal demi hukum. Oleh sebab itu pelaksanaan dispensasi kawin pada anak di bawah umur di Kabupaten Polewali Mandar tidak berjalan efektif.

Adapun faktor-faktor yang mempengaruhi keputusan hakim dalam mengabulkan permohonan dispensasi kawin yaitu: Karena kedua calon mempelai Telah melakukan hubungan biologis sebelumnya sehingga menyebabkan hamil di luar nikah dan karena hakim tidak terikat dengan hukum positif jadi hakim diberikan kesempatan dalam menemukan hukum dengan pertimbangan bahwa apabila undang-undang menetapkan hal-hal tertentu untuk peristiwa tertentu, berarti peraturan itu terbatas pada peristiwa tertentu. Hakim lebih mengedepankan konsep maslahah mursalah, dimana hakim memilih pertimbangan kebaikan dan menolak kerusakan dalam masyarakat serta mencegah kemudharatan. 


\section{SARAN}

Bagi orang tua hendaknya memberikan pendidikan yang baik sejak dini bagi anaknya, memberikan pemahaman agama sebagai pedoman hidup dan memberi perhatian lebih terhadap segala prilaku anak-anaknya baik di dalam atau di luar rumah agar tidak terjerumus dalam hal-hal yang melanggar syariat. Untuk mencapai tujuan perkawinan maka masalah usia perkawinan perlu diperhatikan kondisi calon suami/isteri tersebut yaitu harus telah matang jiwa raganya agar dapat mewujudkan tujuan perkawinan secara baik tanpa berakhir dengan perceraian dan agar mendapatkan keturunan yang baik dan sehat. Sekiranya PPN memperhatikan hal tersebut.

\section{DAFTAR PUSTAKA}

Abdul Gani. 1991.Himpunan Perundang-undangan dan Peraturan Peradilan Agama. Jakarta : Intermasa.

Abdul Azis Dahlan. 2000. Ensiklopedi Hukum Islam Jilid 5 Cet 4. Jakarta : Ichtiar Baru Van Hoeve.

Abdul Rohman Dudung. 2006 Mengembangkan Etika Berumah tangga menjadi moralitas bangsa menurut pandangan Al-qur`an, Bandung: Nuasa Aulia.

Abdurrahman. 1995. Kompilasi Hukum Islam di Indonesia. Jakarta: Akademika Pressindo.

Afandi, Ali. 1997. Hukum Waris Hukum Keluarga Hukum Pembuktian. Jakarta :Rineka Cipta.

Adhim, Mohammad Fauzil. 2006. Indanya Pernikahan Dini. Jakarta: Gema Insani.

Al-Quran dan Terjemahannya. Bandung : Madina.

Ali Akbar. 1995. Merawat Cinta Kasih Cet.20. Jakarta:Pustaka Andara.

Ali, Mohammad Daud.1993. Hukum Islam, Pengantar ilmu Hukum dan Tata Hukum Islam di Indonesia. Jakarta: Raja Grafindo Persada.

Aminuddin, Slamet. 1999. Fiqih Munkahat. Bandung : Cv Pustaka Setia.

Arikunto, Suharsimi. 1993. Prosedur Penelitian Pendekatan Praktek. Jakarta: Rineka Cipta.

Arto Mukti. 2007. Praktek Perkara Perdata Pada Pengadilan Agama. Yogyakarta :Pustaka Pelajar.

Djalil H. A. Basiq. 2006. Peradilan Agama di Indonesia . Jakarta:Kencana. 
Djubaedah, Neng. 2010. Pencatatan Perkawinan dan Perkawinan Tidak Dicatat Menurut Hukum Tertulis Di Indonesia Dan Hukum Islam. Jakarta: Sinar Grafika.

Faridl Miftah.1999. 150 Masalah Nikah Keluarga. Jakarta: Gema insani.

Gautama, Sudargo.1973. Segi-segi Hukum Peraturan Perkawinan Campuran. Bandung :Alumni.

Hadikusuman, Hilman. 1990. Hukum Perkawinan Indonesia Menurut Perundangan,Hukum Adat dan Hukum Agama. Bandung: Mandar Maju.

Haeruddin, Ahrum. 1999. Pengadilan Agama (Bahasan Tentang Pengertian Pengajuan Perkara dan Kewenangan Pengadilan Agama setelah Berlakunya Undang-Undang No.7 Tahun 1989 Tentang Pengadilan Agama). Bandung : Citra Aditya Bakti.

Hutagalung, Mura P, 1985. Hukum Islam Dalam Era Pembangunan. Jakarta : Ind.Hilco.

Ichsan, Achmad. 1986. Hukum Perkawinan Bagi yang beragama Islam,( Jakarta: PT.Pradnya Paramita.

Ilyas khatisah. 1985. Bahasa Kawin di bawah Usia 16 Tahun. Nasihat Perkawinan dan Keluarga (No.125/x) 30 Oktober 1985, Hal 20-25.

Indonesia. 2006. Amandemen Undang-undang Peradilan Agama UU RI Tahun 2006. Jakarta : PT Sinar Grafika.

Jawad Mugniyah, Muhammad. 2005. Fiqih Lima Mazhab. Jakarta : Lentera.

Manan, Abdul. 2003. Aneka Masalah Hukum Material Dalam PraktekPeradilan Agama. Jakarta : Pustaka Bangsa Press.

Muchtar, Kamal,. 1974. Asas- Asas Hukum Islam Tentang Perkawinan. Jakarta: Bulan Bintang.

Mudzhar, H.M Atho dan Khairuddin Nasution. 2003. Hukum Keluarga di Dunia Islam Modern. Jakarta : Ciputat Press.

Nawi, Syahruddin. 2014. Penelitian Hukum Normatif Versus Penelitian Hukum Empiris. Makassar : PT. Umitoha Ukhuwah Grafika.

Nugroho, Kampono. 2007. Pernikahan Dini Tingkatkan Resiko Kanker Servic. Semarang : Kelud Raya.

Pasamai, Syamsuddin. 2013. Metodologi Penelitian dan Penulisan Karya Ilmiah Hukum. Makassar : Arus Timur.

Prawirohamdjojo, R. Soetojo. 1988. Pluralisme Dalam Perundang-undangan Perkawinan Indonesia. Surabaya : Universitas Airlangg.

Rauf A. Ma'mun. 1996. Hukum Islam (lanjutan). Ujung Pandang.

Ramulyo, Mohd, Idris. 1996. Hukum Perkawinan Islam. Jakarta : Bumi Aksara. 
Salam Lubis, Menuju Keluarga sakinah Mawaddah \& Warahmah, (Surabaya:Terbit Terang)

Soemeyati,. 1986. Hukum Perkawinan Islam dan Undang-Undang Perkawinan (Undang-undang Nomor 1 Tahun 1974). Yogyakarta : Liberti.

Sosilo dan Pramudji. 2007. Kitab undang-Undang Hukum Perdata. Jakarta : Wipress.

Sudarsono. 2005. Hukum Perkawinan Nasional. Jakarta: Rineka Cipta.

Syarifuddin, Amir. 2007. Hukum Perkawinan Islam di Indonesia antara fiqh Munakahat dan Undang-undang Perkawinan. Jakarta : Kencana.

Thalib Sajuti. 1974. Hukum Kekeluargaan Indonesia. Jakarta : UI Press.

Sudarsono. 1991. Hukum Kekeluargaan Nasional. Jakarta : Rineka Cipta.

Usman, Rachmadi. 2006. Aspek-aspek Hukum Perorangan dan Kekeluargaan di Indonesia. Jakarta :Sinar Grafika.

\section{Undang-Undang}

Undang-undang Nomor 22 Tahun 1946 tentang Pencatatan Nikah, Talak, dan Rujuk.

Undang-undang Nomor 1 Tahun 1974 Tentang Perkawinan

Undang-undang Nomor 7 Tahun 1989 tentang Peradilan Agama.

Undang-undang Nomor 3 Tahun 2006 Tentang Perubahan Atas Indonesia, Undang-undang Nomor 7 Tahun 1989 Tentang Peradilan Agama.

Peraturan pemerintah Nomor 9 Tahun 1975 Tentang Peraturan Pelaksanaan Undang-undang Nomor 1 Tahun 1974 Tentang Perkawinanilan Agama. Jakarta : Intermasa.

Abdurrahman. 1995. Kompilasi Hukum Islam di Indonesia. Jakarta: Akademika Pressindo.

Djubaedah, Neng. 2010. Pencatatan Perkawinan dan Perkawinan Tidak Dicatat Menurut Hukum Tertulis Di Indonesia Dan Hukum Islam. Jakarta : Sinar Grafika.

Jawad Mugniyah, Muhammad. 2005. Fiqih Lima Mazhab. Jakarta : Lentera. Nawi, Syahruddin. 2014. Penelitian Hukum Normatif Versus Penelitian Hukum Empiris. Makassar : PT. Umitoha Ukhuwah Grafika.

Pasamai, Syamsuddin. 2013. Metodologi Penelitian dan Penulisan Karya Ilmiah Hukum. Makassar : Arus Timur. 